\title{
Erratum zu: Public Relations klipp \& klar
}

Erratum zu: C. Rennhak, Public

Relations klipp \& klar https://doi.org/10.1007/978-3-658-

27250-0

Das Buch wurde mit falscher Reihenfolge der Autorennamen publiziert. Dies wurde korrigiert und die korrekte Reihenfolge ist: 1. Carina Schmidt; 2. Carsten Rennhak. 